\title{
Ensenyar a aprendre: un aspecte fonamental de la nostra professió
}

\author{
Anna Sardà Jorge \\ Escola Avenç (St. Cugat del Vallès) - Fundació Collserola i Universitat Autònoma de Barcelona \\ asarda@fcollserola.cat
}

Per a l'alumnat d'ESO no és fàcil entendre el desenvolupament d'una seqüència didàctica, concretar les novetats que li aporta, desenvolupar les tasques correctament, comprendre $i$ rectificar les seves equivocacions, expressar arguments o definicions amb sentit... Una part molt fonamental de la nostra feina és ajudar-los a aconseguir-ho i a esdevenir, així, estudiants cada vegada més autònoms.

Perquè els nostres alumnes aprenguin no és suficient ensenyar. La nostra experiència de cada dia ens porta a la mateixa conclusió que moltes aportacions teòriques.

Ensenyar no és només comunicar, transmetre uns coneixements. Durant el procés que cada noi i noia ha de fer per apropiar-se aquests coneixements ha de realitzar operacions mentals complexes que de vegades no pot completar sense ajut.

Quines són aquestes operacions? Com els podem ajudar a realitzar-les?

\section{Tres camps de treball}

Sense pretendre exhaurir el terreny, és possible plantejar la intervenció del professorat en tres direccions:

- El suport al treball de competències cognitivolongüístiques: argumentar, justificar, definir, Ilegir amb profit...

- L'orientació de la reflexió sobre les activitats didàctiques i els seus processos: autoavaluació, coavaluació, concreció de criteris, metareflexió sobre les pràctiques, els exàmens...

- I un constant suport anímic, valorar els petits èxits, no abandonar mai, tenir molta paciència...

A continuació veurem, molt breument, algunes de les activitats concretes per treballar alguns d'aquests aspectes. Totes corresponen a algun nivell d'ESO.

\section{Orientar-se en les activitats}

Es tracta de preguntar-se sovint què fem i per què ho fem. Han d'anar aclarint quin és l'objectiu que el professorat està perseguint, cosa que no sempre els resulta senzill. El principal recurs és demanar sovint: Per què estem fent això? Què hem aconseguit, fins ara? Què ens falta fer? Quins passos hem de fer a continuació?

\section{Activitats inicials}

Fer preguntes sobre el tema que s'inicia, combinant les que ja poden contestar, perquè ja ho han estudiat o perquè són idees simples o intuïtives, relacionades amb coneixements quotidians, amb aquelles que els creen dubtes i que generen discussió i que són un primer pas per avançar en la construcció de nou coneixement:

- Ordena les següents parts de la matèria segons la grandària que penses que tenen: àtom, nucli atòmic, nucli cel-lular, element, protó, molècula, mitocondri. Així tant nosaltres com ells podem ser conscients de les concepcions que tenen sobre organització de la matèria, i també dels punts foscos que caldrà anar aclarint. Al final de la seqüència s'hi pot tornar per comprovar si ha estat així.

- Es proporciona una llista (mosca, llentia, closca de cargol, pirita, riu, rovelló...) i es demana de completar la frase "és viu (o no és viu) perquè..." per a cadascun d'ells. Després, per grups, els agrupen segons que consideren quins són vius, 
els que no ho són, i els que no tenen clars. Finalment, han d'escriure les característiques comunes que consideren que tenen els éssers vius.

- Es proporciona una petita llista de conceptes o idees (ones sísmiques, plaques tectòniques, evidència, roca metamòrfica...) i es demana que valorin amb quin grau de seguretat ho sabrien explicar (des de "no en sé gairebé res" fins a "podria fer-ho entendre a un company o companya" passant per graus intermedis). Després de contestar-ho es pot demanar a un alumne que considera que podria explicar alguns dels conceptes, que ho intenti. No sempre ho aconsegueix i, per tant, haurà revisar la seva resposta. Després de la seqüència es pot tornar a reprendre la mateixa activitat per tal d'adonar-se del que han progressat.

- Utilitzar la introducció i el llistat d'objectius del llibre per demanar que concretin què creuen que aprendran i fer que escriguin algunes "bones preguntes" sobre el tema. Després s'analitzen els objectius que han proposat (massa literals del llibre, poc concrets o massa generals, bones síntesis...) i també les bones preguntes (massa limitades, poc relacionades amb el tema, preguntes "de llibre", qüestions realment bones...). Així es van concretant i apropiant dels objectius de la unitat.

\section{Activitats experimentals}

Acompanyar les activitats experimentals amb preguntes que busquen provocar la reflexió sobre el que estan fent:

- Durant l'estudi de la germinació, es demana que dibuixin com s'imaginen una mongeta seca per dins i que la descriguin. S'anoten els dubtes que hagin sorgit quan es comparen amb els companys i companyes. Es fa el mateix amb una mongeta seca que ha estat en remull i, finalment, s'obre una mongeta seca i es repeteix l'operació. Es comparen els tres dibuixos i s'anoten allò que els ha sorprès, què era el que no s'imaginaven. Després es proporciona un llistat i una descripció de les parts observables perquè incorporin els noms al seu dibuix. Es pot completar l'activitat fent una predicció del que passarà quan germini.

- En acabar una pràctica es pregunta què n'han après, diferenciant-ho dels coneixements utilitzats per entendre-la, ja que els costa diferenciar una cosa de l'altra.

- Establir entre tots uns criteris d'avaluació dels informes de pràctiques. Triar els grans apartats que haurà de tenir l'informe (títol, objectiu principal...) i concretar per a cada apartat criteris per saber si s'ha fet correctament ("estarà ben fet si...") (fig. 1). Aquests criteris es fan servir habitualment per fer l'autoavaluació dels informes mitjançant una graella (fig. 2), així com per coavaluar-los (avaluació mútua entre dos alumnes). En tots els casos s'han d'explicitar els errors comesos o allò que no és prou correcte.

\begin{tabular}{|c|c|}
\hline Accions que he de fer & Estarà ben fet si. \\
\hline 1. Escollir un titol per a l'informe & $\begin{array}{l}1.1 \text { està d'acord amb l'experiència } \\
1.2 \text { resumeix l'objectiu principal } \\
1.3 \text { és suggerent }\end{array}$ \\
\hline 2. Identificar el principal objectiu & $\begin{array}{l}2.1 \text { està d'acord amb les finalitats del treball realitzat } \\
2.2 \text { comença amb un verb }\end{array}$ \\
\hline 3. Plantejar la hipòtesi & $\begin{array}{l}3.1 \text { s'indiquen les variables independent } i \text { dependent } \\
3.2 \text { s'indiquen les variables que es controlen } \\
3.3 \text { es redacten utilitzant la forma: }\end{array}$ \\
\hline $\begin{array}{l}\text { 4. Indicar els materials i } \\
\text { instruments utilitzats durant } \\
\text { l'experimentació }\end{array}$ & $\begin{array}{l}4.1 \text { s'anoten tots } \\
4.2 \text { estan anomenats correctament }\end{array}$ \\
\hline 5. Descriure el procediment seguit & $\begin{array}{l}5.1 \text { està d'acord amb la hipòtesi } \\
5.2 \text { es descriuen els diferents passos en paràgrafs } \\
\text { separats } \\
5.3 \text { els paràgrafs són curts, precisos i concisos } \\
5.4 \text { s'acompanyen amb esquemes }\end{array}$ \\
\hline $\begin{array}{l}\text { 6. Transcriure les observacions } \\
\text { les dades }\end{array}$ & $\begin{array}{l}6.1 \text { són sistemàtiques en relació a la variable } \\
\text { independent } \\
6.2 \text { es poden utilitzar taules i quadres } \\
6.3 \text { es visualitzen fàcilment } \\
6.4 \text { inclouen observacions sobre aspectes divergents o } \\
\text { d'altres }\end{array}$ \\
\hline 7. Transformar les dades & $\begin{array}{l}7.1 \text { si permeten visualitzar } i \text { arribar a conclusions en } \\
\text { relació a la hipòtesi plantejada } \\
7.2 \text { si s'utilitzen gràfics o esquemes }\end{array}$ \\
\hline 8. Redactar les conclusions & $\begin{array}{l}\text { 8.1 respon a la hipòtesi } \\
8.2 \text { es relaciona amb aspectes teòrics que 'expliquen' } \\
\text { els resultats obtinguts } \\
8.3 \text { es diferencien les interpretacions personals de les } \\
\text { que són acceptades cientificament } \\
8.4 \text { queda clar el que s'ha après, els conceptes que cal } \\
\text { saber per entendre l'experiment, i el que no ha quedat } \\
\text { clar } \\
8.5 \text { en la redacció s'utilizen els termes cientifics } \\
\text { adequats i sense errors } \\
8.6 \text { si les frases estan ben construìdes (atenció als } \\
\text { connectors) }\end{array}$ \\
\hline 9. Revisar el text elaborat & $\begin{array}{l}\text { 9.1 es comprova que una persona que no ha fet } \\
\text { l'experiment el podria repetir } \\
9.2 \text { la presentació permet llegir fàcilment el text } \\
9.3 \text { la puntuació i l'ortografia són correctes }\end{array}$ \\
\hline
\end{tabular}

Figura 1. Criteris d'avaluació d'un informe de laborato

\section{Resolució de problemes}

- La dificultat és desxifar els enunciats, és a dir, saber entendre la situació, comprendre què es demana, quins són els passos que s'hauran de fer i resoldre les dificultats que sorgeixen. Es resol un problema posant-hi una doble atenció: a la resolució pròpiament dita i al procés que s'ha hagut de fer. S'anoten els passos, incloent-hi la possibilitat de concretar dubtes, de descartar dades que no seran útils, de concretar dades necessàries que no hi apareixen, demanar que es justifiquin cadascun dels passos o càlculs que s'hi fan, justificar la correcció del resultat... Els dubtes que s'han anotat es discuteixen a continuació. En problemes posteriors es demana que es tinguin en compte tots aquests passos i s'autoavalua i coavalua si s'han fet bé o no. 


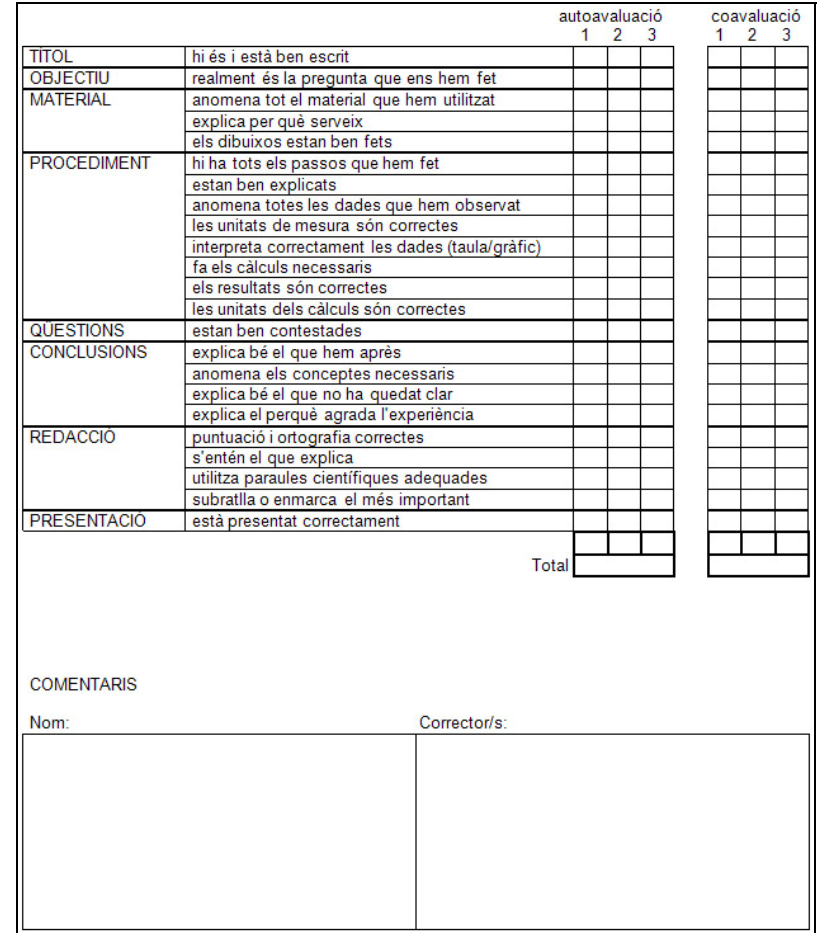

Figura 2. Graella per a l'avaluació d'un informe.

\section{Orientar-se en el tema}

Es tracta d'ajudar-los a situar en la complexitat de les activitats d'un tema i a destriar allò essencial d'allò que no ho és:

- En un moment inicial es recullen els dubtes expressats com a preguntes i s'analitzen un per un: És un bon dubte, en aquest punt del tema? Per què? Ajuda a fer-se les preguntes rellevants a cada moment.

- Confeccionar una llista d'idees essencials del tema, posant-la en comú. Cada alumne valora, de cada idea, si l'ha après, si l'hauria d'haver après, o si no s'entén què vol dir. Ajuda a tenir clar què és el més rellevant.

\section{Reflexionar i aprendre dels exàmens}

Els exàmens han de permetre als estudiants descobrir els punts dèbils dels seus aprenentatges per tal de poder-los solucionar:

- Demanar que descriguin alguns dels errors que han comès, que pensin per què l'han comès, $i$ que proposin o busquin la manera d'esmenar-lo.

- Proporcionar una llista de frases que els alumnes d'agun altre curs van escriure quan analitzaven cadascun dels seus errors i justificaven la forma com s'havien produït. Demanar que els classifiquin segons que els semblin excuses (raons poc convincents), justificacions massa genèriques, i bones raons. Finalment, en petits grups, concreten què tenen en comú les bones raons. D'aquesta manera es pretén que es centrin en allò que és realment rellevant.

- Analitzar un examen que la professora ja ha puntuat. Es fan preguntes a l'alumne sobre aspectes formals de la prova (entens el que es pregunta? sinó, què és el que no queda clar?). Cada alumne analitza es respostes d'una companya o company (la resposta queda clara o s'ha de fer un esforç per interpretar-la? per quina causa: cal-ligrafia, sintaxi? les faltes d'ortografia dificulten comprendre el que hi diu?...) i també referides al seu contingut (respon sobre allò que es demana? què s'ha oblidat d'escriure? diu coses amb poca vinculació al tema? què més no ha fet bé?). Finalment l'exercici torna a mans de l'autor de l'examen i se li pregunta sobre les equivocacions que ha comès (per què creus que no ho has sabut contestar o per què no ho has fet prou bé? en un altre full escriu la teva nova resposta millorada). Cal tenir present que fer aquest tipus de reflexions és una tasca poc grata per a l'alumnat, al principi, i els costa entendre què han de fer o no saben com posar-s'hi... Per tant, no es pot fer ni de cada examen, ni de totes les preguntes i és molt important animar-los durant el procés i valorar positivament els petits avenços que van fent.

\section{Aprendre a pensar i a expressar-se}

Pensar i utilitzar el llenguatge (parlar, escriure, llegir, escoltar...) són habilitats que no es poden deslligar. Per això es diuen habilitats cognitivolingüístiques. Dominar el llenguatge propi de la ciència requereix saber ciències, però pensar sobre ciències correctament exigeix un ús acurat del llenguatge (Sanmartí, 2003).

És per això que aprendre a pensar científicament passar per aprendre a explicar, justificar, definir...

\section{Justificar i argumentar}

A classe de ciències fem moltes preguntes del tipus: per què...? justifica... raona... explica... que demanen una bona comprensió del que es treballa per tal de poder escriure bones respostes. Cal ferlos adonar que sovint les respostes que redacten no són autèntiques justificacions perquè no concreten el perquè del perquè:

- Proporcionar una pregunta d'un exercici (a partir del resultat d'un experiment dos alumnes tenen opinions contraposades sobre si es tracta d'un canvi físic o químic i demana que es justifiqui 
amb qui dels dos s'està d'acord). En una activitat per parelles se'ls pregunta què demana l'exercici exactament. Es proporcionen unes pautes per resoldre l'exercici i es demana que hi segueixin els passos (quins són els fets que es tracten, quines idees cal tenir presents, possibles raons, i triar-ne les més rellevants). Un cop acabat l'exercici es demana de redactar un possible text justificatiu, utilitzant els connectors adequats (del tipus: perquè, a causa de, ja que, però, sinó, encara que, per tant, en conseqüència...). Una altra parella llegeix el redactat i avalua què considera punts correctes i incorrectes. La parella original pot analitzar cadascuna de les anotacions dels companys i argumentar el seu acord o desacord.

- Proporcionar dades sobre un problema real de gestió ambiental (la construcció d'un camp de golf) i demanar que es proposi una solució, argumentant-la des de diversos punts de vista (utilitzant conceptes d'ecologia ja estudiats, les idees sobre com ha anat el procés, els personatges i entitats que hi estan implicats, qüestions al voltant del corredor biològic, de l'aigua, de la vegetació i els animals, dels factors abiòtics que es veurien alterats...), i tenint en compte l'estructura, treballada anteriorment, d'un text argumentatiu (fig. 3).

TEXT ARGUMENTATIU

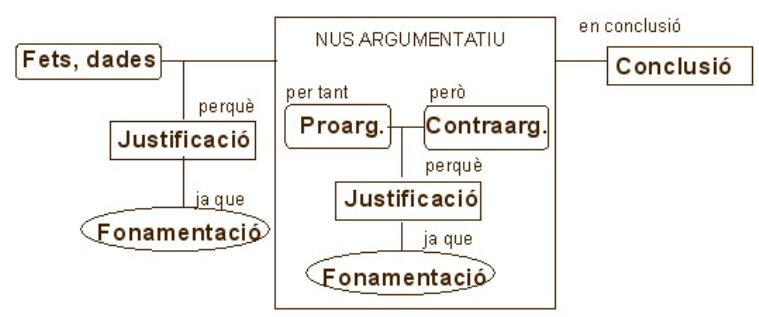

Dades. Fets i fenòmens que constitueixen l'afirmació inicial sobre la qual es construeix el text argumentatiu.

Justificació. Raó principal. S'ha de referir a un camp de coneixement específic, en aquest cas de la ciència, o també el camp social, ètic, moral...

Fonamentació. Coneixement bàsic de caràcter teòric necessari per acceptar la justificació. També s'ha de referir a un camp de coneixement especific.

Argumentació. Conjunt dels arguments del text que, de forma retòrica reforcen la justificació principal i li donen els criteris de validació.

Proargument. Comentari implícit que reforça l'afirmació principal i en destaca els elements positius.

Contraargument. Comentari implícit que assenyala les circumstàncies de desavantatge.

Conclusió. És el valor final que es vol assolir a partir de la tesi inicial i segons les condicions que inclouen els diferents arguments.

Figura 3. Estructura d'un text argumentatiu. (Sardà, 1998, 1999, 2000).
A partir d'aquest treball de l'argumentació durant les discussions sobre la rellevància i pertinença dels arguments, la concordança entre fets i conclusions, la fonamentació de les raons... es van treballant, a fons, els diferents continguts d'ecologia. És una feina que permet avançar en ambdues direccions.

\section{Definir}

No és possible fer una bona definició fins que el concepte està ben entès i s'ha utilitzat prou. Tampoc no és possible entendre un concepte i no poder-lo definir:

- Després de l'estudi dels sòlids, mostrar als alumnes definicions de sòlid de diferent procedència (d'un alumne, d'un diccionari i d'un llibre de text), demanant, per parelles, que escrigui aspectes positius $\mathrm{i}$ aspectes negatius de cadascuna. Després de discutir-ho es demana que escriguin què és una definició, i quina estructura hauria de tenir. Es demana que ho intentin aplicar amb un altre concepte del tema actual. El resultat és analitzat per una altra parella, que fa constar els seus punts d'acord i/o de desacord. La parella inicial escriu el que pensa dels comentaris i revisa, si cal, la seva formulació original.

El fet d'anar aclarint les diverses definicions permet, alhora, aprofundir en alguns aspectes dels conceptes científics treballats.

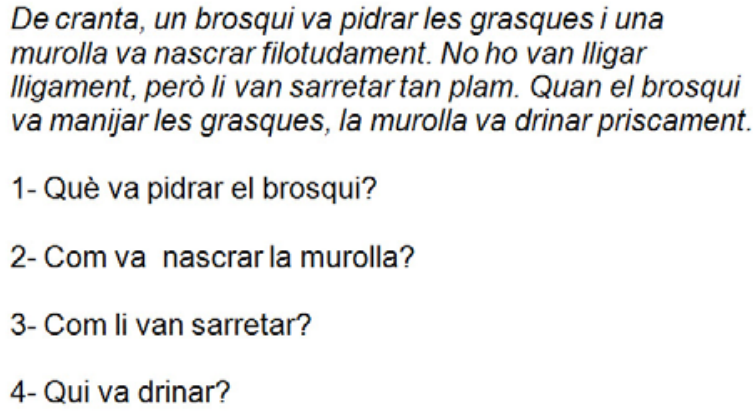

Figura 4. Text sense sentit i preguntes que aparentment es poden respondre correctament. Font: Sanmartí (2003).

\section{Llegir}

No sol resultar fàcil als alumnes d'ESO comprendre bé el que llegeixen, i encara menys els Ilibres de ciències. Per això cal ajudar-los a entendre com funciona la lectura i proporcionar-los estratègies útils:

- Per evidenciar la diferència entre contestar preguntes i entendre-les és útil el suposat exercici de la fig. 4. Es demana als estudiants que con- 
testin les preguntes i que expliquin per què creuen que en són capaços.

- Demanar de subratllar les cinc paraules més importants d'una part del llibre de text. Cadascú escriu la justificació de la tria de cada paraula. També el tipus de paraules: substantius, adjectius, verbs... Es discuteix quins tipus de paraules són més útils de subratllar i per què. Es consensua una sola llista de paraules subratllades i s'analitza la seva rellevància en el tema que s'està estudiant. Per votació se'n trien 10. Es demana a l'alumnat què creuen que hauran de fer amb les paraules. Efectivament, apunten la possibilitat de fer-ne frases o mapes conceptuals. Com a deures han d'escriure frases curtes que tinguin relació amb el tema. L'endemà es discuteix la rellevància de les frases elaborades.

- Davant d'un text del llibre sobre els virus es proposa llegir-lo individualment, però repartint tasques a cadascun dels quatre components d'un grup (trobar la idea principal, escriure les preguntes a les quals sembla respondre el text, les principals informacions que aporta, i noves preguntes o idees que sorgeixen al llegir-lo). Després han de fer una posada en comú per comprovar si tot encaixa i elaborar una síntesi de la lectura. També es comenta la utilitat de l'estratègia que s'ha fet servir.

\section{Resultats}

Les primeres vegades que s'intenten aplicar estratègies d'aquesta mena els estudiants hi solen oposar resistència ja que semblen no encaixar amb la seva concepció del que ha de ser una classe. Ai$x i ́$, en els qüestionaris inicials d'un tema els costa entendre que les seves respostes no siguin ni correctes ni incorrectes; es neguen a fer-les amb bolígraf, pensant que poden estar malament; i reflexionar els costa, ja que es tracta de situar-se en un nivell d'anàlisi al qual, sovint, no hi estan acostumats. Per tot això, el primer trimestre sol resultar força dur fins que, de mica en mica, van entrant en el joc.

Els resultats es veuen millor a la llarga. En un grup d'escoles es van realitzar proves similars a les PISA al final de quart d'ESO, basades en competències. En el grup que havia rebut formació, segons el contingut exposat en el present article, durant els quatre cursos d'ESO (E3 grup C, taula 1) el percentatge de noies i nois amb rendiment inferior resulta sensiblement menor que en altres grups. I això, sense perjudicar el rendiment dels alumnes amb millors resultats.

\begin{tabular}{|crrr|}
\hline Grup & Nivell 1 & Nivell 2 & Nivell 3 \\
\hline E1 grup A & 53,3 & 40,4 & 6,3 \\
E1 grup B & 50,0 & 46,4 & 3,6 \\
E1 grup C & 56,7 & 40,0 & 3,3 \\
E1 grup D & 72,4 & 27,6 & 0,0 \\
E1 grup E & 67,9 & 32,1 & 0,0 \\
E2 grup A & 36,0 & 48,0 & 16,0 \\
E2 grup B & 35,7 & 57,1 & 7,2 \\
E3 grup A & 32,1 & 57,1 & 10,8 \\
E3 grup B & 24,0 & 68,0 & 8,0 \\
E3 grup C & 11,5 & 73,1 & 15,4 \\
\hline
\end{tabular}

Taula 1. Resultats, expressats en percentatges, del nivell assolit per l'alumnat de diversos grups de quart d'ESO de tres escoles (E1, E2 i E3). El grup experimental era el darrer, indicat amb cursiva. Dels tres nivells de competència que hi apareixen, l'1 és l'inferior.

En definitiva, la constància, el no desanimar-se i la insistència en la metareflexió poden significar, per a molts nois i noies, la diferència entre l'èxit i el fracàs escolar.

\section{Bibliografia}

SANMARTÍ, N. (coord) Calvet, M.; Custodio, E.; Estanya, J.L.; Franco, R.; Garcia, M.P.; Izquierdo, M.; Marquez, C.; Oliveras, B.; Ribas, N.; Roca, M.; Sardà, A.; Solsona, N. i Via, A. (2003) GRUP LIEC (Llengua i Ensenyament deles Ciències - UAB), Aprendre ciències tot aprenent a escriure ciència. Barcelona: Edicions 62 - Sèrie Rosa Sensat, núm. 386. ISBN: 84-297-5323-0.

SANMARTí, N. (2002). Didáctica de las Ciencias en la Educación Secundaria Obligatoria. Madrid: Síntesis.

SARDÀ, A.; SANMARTí, N. \& MÁRQUEZ, C. (1998) Com podem ensenyar a argumentar científicament. Perspectiva escolar, 230, 23-35.

SARDÀ, A. (1999) Una estratègia per ensenyar a argumentar a les classes de ciències. Actes del 5è Simposi sobre l'ensenyament de les Ciències de la Naturalesa: Recerca i innovació a l'aula de ciències de la naturalesa. Manresa, 4-6 de febrer de 1999, pp. 519-530. ISBN: 84-88894-29-5.

SARDÀ, A. i SANMARTÍ, N. (2000) Ensenyar a argumentar científicament: un repte de les classes de ciències. Enseñanza de las Ciencias 18 (3), 405-422. 